\title{
TOMOGRAPHIC FINDINGS OF GASTRIC GASTROINTESTINAL STROMAL TUMOR AND CORRELATION WITH THE MITOTIC INDEX
}

\author{
Gustavo Lemos PELANDRÉ1, Maria Célia DJAHJAH², \\ Emerson Leandro GASPARETTO², Marcelo Souto NACIF ${ }^{3}$, \\ Edson MARCHIORI ${ }^{2}$ and Eduardo Linhares Riello de MELLO ${ }^{4}$
}

\begin{abstract}
Context - Gastrointestinal stromal tumors are uncommon abdominal neoplasms and can affect any portion of the gastrointestinal tract. Objectives - Describe the tomographic findings of the gastrointestinal stromal tumor of gastric origin, correlating it with the mitotic index. Methods - Twenty-one patients were selected within the period of January 2000 and 2008, with histopathological and immunohistochemical diagnosis of gastric gastrointestinal stromal tumors, who presented computed tomography done before the treatment. The tomographic variables analyzed were lesion topography, dimensions, contours, morphology, pattern and intensity enhancement through venous contrast, growth pattern, invasion of adjacent organs, presence of ulceration, fistula, calcifications, infiltration of mesenteric fat, lymphadenopathy and metastasis. The mitotic index was determined through optic microscopy, counting the number of mitosis figures in 50 high power fields. Results - The tumors were located in the body (66.7\%) or gastric fundus (33.3\%), with dimensions varying between 4.2 and $21.2 \mathrm{~cm}$ (average of $10.5 \mathrm{~cm}$ ). The growth was predominantly extraluminal $(47.6 \%)$ or intra/extra luminal $(28.6 \%)$. The enhancement by venous contrast was heterogeneous in $66.7 \%$. The statistical analysis showed that irregular morphology $(P=0.027)$ and infiltration of mesenteric fat $(P=0.012)$ presented correlation with the high mitotic index. Conclusions - In the present study, most part of the tumors were located in the gastric body, with average size of $10.5 \mathrm{~cm}$, presenting central hypo dense area, heterogeneous enhancement through contrast and predominantly extra luminal growth. Irregular morphology and infiltration of mesenteric fat present statistical correlation with high mitotic level.
\end{abstract}

HEADINGS - Gastrointestinal stromal tumors. Spiral computed tomography. Mitotic index.

\section{INTRODUCTION}

Gastrointestinal stromal tumors or GISTs are uncommon abdominal neoplasias, but that represent the most frequent mesenchymal tumors of the digestive tract $(80 \%)$ and $5 \%$ of all sarcomas ${ }^{(1)}$. The disease can affect any portion of the gastrointestinal tract, being the stomach the most affected organ (45\% to $65 \%$ ), followed by the small intestine ( $15 \%$ to $25 \%$ ), colon $(5 \%$ to $10 \%)$ and other regions of the abdominal cavity $(5 \%)^{(6)}$.

Approximately 4,500 to 6,000 cases of GIST are diagnosed annually in the USA, with an incidence pick between the sixth and seventh decades of life, representing around $1.0 \%$ to $3.0 \%$ of gastric tumors, $20 \%$ of the small intestine tumors, and $0.2 \%-0.1 \%$ of colorectal tumors $^{(2,26)}$.

Although this mesenchymal neoplasia has been known for decades, recent findings have allowed a better knowledge of its cellular origin, as well as the molecular events involved in the lesion ${ }^{(6)}$. For about 20 years, we believed that most mesechymal tumors were originated in the smooth muscles, being called "leyomiomas" and "leyomiossarcomas". The utilization of electronic microscopy and immunohistochemistry, however, showed that only some of these tumors presented smooth muscle characteristics ${ }^{(24)}$. Afterwards, some authors demonstrated that these tumors also presented characteristics of neuronal differentiation, denominating them "plexossarcomas" and "gastrointestinal tumors of the autonomic nerve"(19). Just recently it was clarified that this neoplasia constitutes one well defined entity denominated GIST, through the discovery of its origin from Cajal's interstitial cells $^{(17)}$, and the expression of the kit protein ${ }^{(12)}$. Kit is a transmembrane receptor with tyrosine kinase

Declared conflict of interest of all authors: non

Colégio Brasileiro de Radiologia (CBR), São Paulo, SP, Brasil; ${ }^{2}$ Departamento de Radiologia da Universidade Federal do Rio de Janeiro (UFRJ), RJ, Brasil; ${ }^{3}$ Departamento de Radiologia da Universidade Federal Fluminense (UFF), Niterói, RJ, Brasil; ${ }^{4}$ Departamento de Cirurgia Oncológica do Instituto Nacional de Câncer (INCA), Rio de Janeiro, RJ, Brasil.

Research performed at: Hospital do Câncer I, Instituto Nacional de Câncer, Rio de Janeiro, RJ, Brasil.

Correspondence: Gustavo Lemos Pelandré. Rua Luiz Delfino 89, ap 801 A - 88015-360 - Florianópolis - SC, Brasil. Email:gupelandre@gmail.com 
activity, responsible for various cellular functions, such as adhesion, apoptosis, and differentiation. In the GIST, the mutation of the gene kit is responsible for the constitutive activation in the kit protein, which causes stimulus without the opposition for cell proliferation ${ }^{(14)}$.

Computed tomography is the most important image modality to detect and characterize the GIST, once it provides information about the size of the tumor, anatomic, growth pattern, necrosis evidence, invasion of adjacent organs, and metastasis, also allowing treatment monitoring and the assessment of the disease progression ${ }^{(5,32)}$. Some authors still describe the association among tomography variables and the high tumor degree, however these finding are conflicting and there is no consensus, which makes the prediction of the biological behavior of the tumor through image characteristics problematic ${ }^{(13,16,21,26,32-34)}$. In recent years, the malignity potential has been classified according to the tumor site, size, and mitotic index ${ }^{(26)}$.

The authors aim at describing the tomography aspects of a group of 21 patients with gastric GIST, as well as to determine its importance for the prediction of the behavior of the tumor, through the correlation with the mitotic index.

\section{METHODS}

We reviewed the clinical, pathological and radiological findings for 39 patients with histopathological diagnosis of GIST who were treated in our institution between January 2000 and December 2008. From those, 18 patients who did not present abdominal computed tomography performed before the oncologic treatment or whose exams were incomplete or were not found, were excluded.

The study population consisted of $14(66.7 \%)$ female patients and $7(33.3 \%)$ male patients. The average age observed was $61.6 \pm 16$ years old (average \pm standard deviation).

The most common presenting features were pain or abdominal discomfort $(n=13)$, weight loss $(n=6)$, abdominal mass $(n=6)$, hematemesis $(n=3)$, melena $(n=2)$, vomiting $(\mathrm{n}=2)$, fever $(\mathrm{n}=1)$, constipation $(\mathrm{n}=1)$, asthenia $(\mathrm{n}=1)$ and anemia $(\mathrm{n}=1)$. One patient was asymptomatic and the tumor was incidentally found on abdominal ultrasound.

Thirteen patients had computed tomography in our institution, in helical device Shimadzu SCT-7000 TS, through axial acquisitions collimation of $5 \mathrm{~mm}$ and reconstruction interval of $7 \mathrm{~mm}$, pitch of $1.5,120 \mathrm{KV}$ and $130 \mathrm{~mA}$. For the opacification of the bowels, $1,000 \mathrm{~mL}$ iodized ionic contrast solution was administrated orally, one hour before each exam (meglumine diatrizoate $2 \%$ ). The images were obtained through two volumetric acquisitions, performed before and after the administration of $100 \mathrm{~mL}$ of iodized non-ionic venous contrast (ioexol $300 \mathrm{mgI} / \mathrm{mI}, 2 \mathrm{~mL} / \mathrm{s}, 55$ seconds after the beginning of the infusion). Eight patients had the computed tomography performed in other institutions, with varied techniques; all of them utilized oral contrast and six used venous contrast.
Three radiologists evaluated all the scans independently. In discordant cases, the final decision was defined by consensus. The assessed data were: lesion topography, size, contours, morphology, pattern and intensity of enhancement through venous contrast, growth pattern, invasion of adjacent organs, presence of ulceration, fistula, calcifications, central hypodensity, mesenteric fat infiltration, lymphadenopathy and metastasis.

In relation to topography, the lesions were classified according to the segment gastric of origin. The contours were classified as regular and irregular. The lesion morphology was defined as round/oval or irregular. The enhancement intensity through venous contrast was compared to the hepatic and abdominal muscles density: mild enhancement if density is equal or inferior to the muscle's enhancement, moderate if density is superior to the muscle and inferior to the liver's enhancement, and marked enhancement if density is superior to the liver's one. The growth pattern was classified according to the predominant component: intra and extraluminal. The cases which presented both components, none of them being predominant, were classified as intra/extraluminal. Lesion dimensions were measured through the measuring of orthogonal plans.

Histopathological findings were revised by a pathologist physician. Most patients, 17 (80.9\%) presented tumors with fusiform cells, $3(14.3 \%)$ with epithelial cells and $1(4.8 \%)$ with mixed cells. All cases had immunohistochemistry confirmation with positivity for c-kit (CD 117).

Mitotic index was determined through optical microscopy, counting the number of mitosis figures in 50 high power fields (HPF). According to the number of mitosis by $50 \mathrm{HPF}$, the patients were classified into 2 groups: $\leq 5$ mitosis per $50 \mathrm{HPF}$ or $>5$ mitosis per $50 \mathrm{HPF}$.

All patients were submitted to surgical treatment: stomach segmental resection in $13(61.9 \%)$ cases, total gastrectomy in $6(28.6 \%)$, and subtotal gastrectomy in $2(9.5 \%)$.

Statistical analysis was performed utilizing Student's $t$ test, Fisher test and chi-square test. Prevalence reason and confidence interval of $95 \%$ were calculated to describe the association between tomography variables and mitotic index. $P$-values smaller than 0.05 were considered statistically significant.

The study was approved by the Human Research Ethics Committee of our institution (project 065/07).

\section{RESULTS}

The main tomography findings of the 21 patients with gastric GIST, as well as the mitotic index found are demonstrated in Table 1 . The tumors were located in the body $(\mathrm{n}=14 ; 66.7 \%)$ and gastric fundus $(\mathrm{n}=7 ; 33.3 \%)$.

Lesion dimensions varied between 4.2 and $21.2 \mathrm{~cm}$, with average size of $10.5 \pm 5.0 \mathrm{~cm}$ (average \pm standard deviation). The tumors with high mitotic index presented average size of $11.4 \pm 5.9 \mathrm{~cm}$, while the ones with reduced mitotic index presented average size of $9.5 \pm 4.2$ (Figure 1). 
TABLE 1. Computed tomographic findings of gastric GIST in 21 patients

\begin{tabular}{|c|c|c|c|c|c|c|}
\hline \multirow{3}{*}{ Criteria } & & \multicolumn{4}{|c|}{ Mitotic index (50 HPF) } & \multirow{3}{*}{$P$-value } \\
\hline & & \multicolumn{2}{|c|}{$\leq 5$} & \multicolumn{2}{|c|}{$>5$} & \\
\hline & & $\mathbf{N}$ & $\%$ & $\mathbf{N}$ & $\%$ & \\
\hline \multirow[t]{2}{*}{ Localization } & Body & 6 & 54.5 & 8 & 80 & \\
\hline & Fundus & 5 & 45.5 & 2 & 20 & 0.22 \\
\hline \multirow[t]{3}{*}{ Size } & $\leq 5 \mathrm{~cm}$ & 1 & 9.1 & 2 & 20 & 0.30 \\
\hline & $5-10 \mathrm{~cm}$ & 7 & 63.6 & 3 & 30 & \\
\hline & $>10 \mathrm{~cm}$ & 3 & 27.3 & 5 & 50 & \\
\hline \multirow[t]{3}{*}{ Growth pattern } & Extraluminal & 6 & 54.6 & 4 & 40 & \\
\hline & Intra/extraluminal & 2 & 18.2 & 4 & 40 & 0.54 \\
\hline & Intraluminal & 3 & 27.3 & 2 & 20 & \\
\hline \multirow[t]{2}{*}{ Enhancement pattern* } & Heterogeneous & 5 & 55.6 & 9 & 90 & \\
\hline & Homogeneous & 4 & 44.4 & 1 & 10 & 0.11 \\
\hline \multirow[t]{3}{*}{ Enhancement intensity* } & Mild & 5 & 55.6 & 6 & 60 & \\
\hline & Moderate & 4 & 44.4 & 4 & 40 & 0.60 \\
\hline & Marked & - & & - & - & \\
\hline \multirow[t]{2}{*}{ Morphology } & Round/oval & 10 & 90.9 & 6 & 60 & \\
\hline & Irregular & 1 & 9.1 & 4 & 40 & 0.027 \\
\hline \multirow[t]{2}{*}{ Contour } & Regular & 10 & 90.9 & 6 & 60 & \\
\hline & Irregular & 1 & 9.1 & 4 & 40 & 0.128 \\
\hline \multirow[t]{2}{*}{ Central hypodense area } & Present & 4 & 36.4 & 7 & 70 & 0.13 \\
\hline & Absent & 7 & 63.6 & 3 & 30 & \\
\hline \multirow[t]{2}{*}{ Mesenteric fat infiltration } & Present & - & - & 5 & 50 & 0.012 \\
\hline & Absent & 11 & 100 & 5 & 50 & \\
\hline \multirow[t]{2}{*}{ Ulcer } & Present & 4 & 36.4 & 7 & 70 & 0.13 \\
\hline & Absent & 7 & 63.6 & 3 & 30 & \\
\hline \multirow[t]{2}{*}{ Calcification } & Present & 1 & 9,1 & 1 & - & 0.73 \\
\hline & Absent & 10 & 90.9 & 9 & 90 & \\
\hline \multirow[t]{2}{*}{ Lympadenopathy } & Present & 1 & 9.1 & - & - & 0.53 \\
\hline & Absent & 10 & 90.9 & 10 & 100 & \\
\hline \multirow[t]{2}{*}{ Fistula } & Present & 2 & 18.2 & 4 & 40 & 0.267 \\
\hline & Absent & 9 & 81.8 & 6 & 60 & \\
\hline \multirow[t]{2}{*}{ Organ invasion } & Present & 3 & 27.3 & 4 & 40 & 0.43 \\
\hline & Absent & 8 & 72.7 & 6 & 60 & \\
\hline \multirow[t]{2}{*}{ Metastasis } & Present & - & - & 1 & 10 & 0.47 \\
\hline & Absent & 11 & 100 & 9 & 90 & \\
\hline
\end{tabular}

*Only for patients receiving intravenous contrast media; HPF: high-power fields; GIST: gastrointestinal stromal tumour

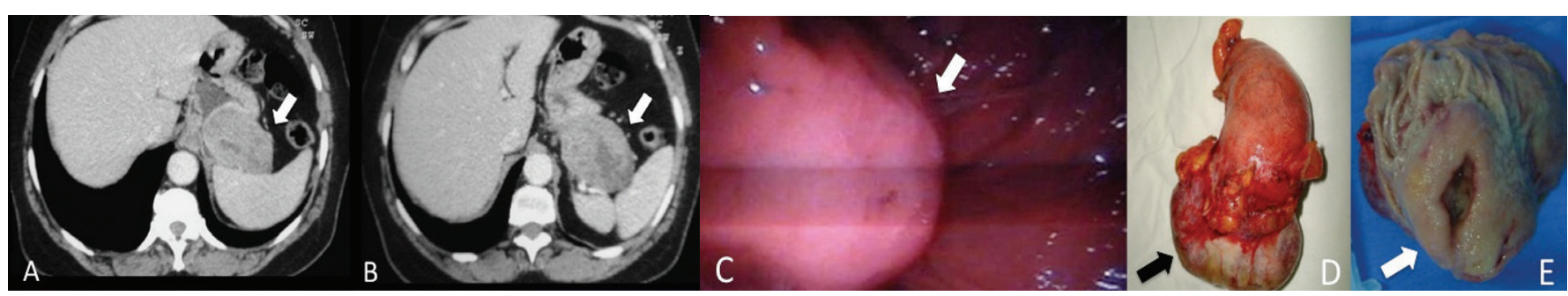

FIGURE 1. A 71 years old male patient, presenting abdominal pain

A and B: computed tomography with oral and venous contrast, showing expansive homogeneous lesion, oval morphology, with extraluminal growth, located in the gastric fundus, measuring $9.0 \mathrm{~cm}$ (arrow); C: photomicrography showing fusiform cells grouped (hematoxylin-eosin stain, original magnification $\times 20$ ). No mitosis figure can be observed (mitotic index of 4 mitosis per $50 \mathrm{HPF}$ ); D: immunohystochemistry of c-kit, with cells cytoplasm stained in brown, indicating positivity. 
Lesion growth was predominantly extraluminal in 10 $(47.6 \%)$ cases (Figure 2), intra/extra luminal in $6(28.6 \%)$ (Figure 3 ) and intraluminal in $5(23.8 \%$ ) (Figure 4). Among the tumors bigger than $10 \mathrm{~cm}, 50 \%$ presented extraluminal growth (Table 2), 37.5\% presented intra/extra luminal growth, and $12.5 \%$ intraluminal. Among the tumors smaller than $5 \mathrm{~cm}, 100 \%$ presented intra luminal growth. Extraluminal tumors presented average size of $12.0 \pm 5.7 \mathrm{~cm}$ and the intraluminal tumors $6.6 \pm 3.0 \mathrm{~cm}$.

Enhancement through venous contrast was heterogeneous in $14(66.7 \%)$ patients and homogeneous in $5(23.8 \%)$. In two $(9.5 \%)$ patients, venous contrast was not utilized. Among the tumors bigger than $10 \mathrm{~cm}, 100 \%$ presented heterogeneous enhancement, while among tumors smaller than $5.0 \mathrm{~cm}, 66.7 \%$ presented homogeneous enhancement (Table 2). Heterogeneous tumors presented average size of $11.9 \%$ $\pm 5.3 \mathrm{~cm}$ and the homogeneous $6.9 \pm 2.2 \mathrm{~cm}$.

The tumors presented oval/round morphology in 16 $(76.8 \%)$ cases and irregular in $5(23.8 \%)$. The presence of irregular morphology was observed in $40 \%$ of patients with high mitotic index (Figure 3 ) and 10\% of the patients with reduced mitotic index.

Mesenteric fat infiltration was observed in $5(23.8 \%)$ patients, corresponding to $50 \%$ of the group with high mitotic level (Figure 3). No patient with low mitotic index presented infiltration of mesenteric fat.

Most patients still presented lesion with regular contours $(76.8 \%)$, central hypodensity area $(52.4 \%)$ and ulceration $(52.4 \%)$. The presence of fistula was observed in six $(28.6 \%)$ patients, intratumoral calcification in two $(9.5 \%)$ and adjacent lymphadenopathy in just one (4.8\%) patient.

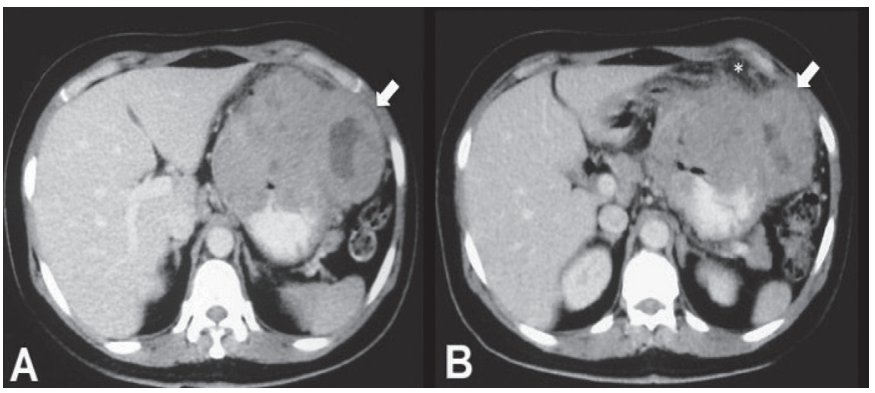

FIGURE 2. A 61 years old female patient, presenting abdominal pain $A$ and B: computed tomography with venous contrast showing expansive heterogeneous mass, predominantly extraluminal, located in the posterior wall of the gastric body (arrow); C: upper digestive endoscopy showing intraluminal component of the tumor; $\mathrm{D}$ and $\mathrm{E}$ : gross pathologic specimen shows predominantly extraluminal growth (D) and the intraluminal aspect of the lesion (E).

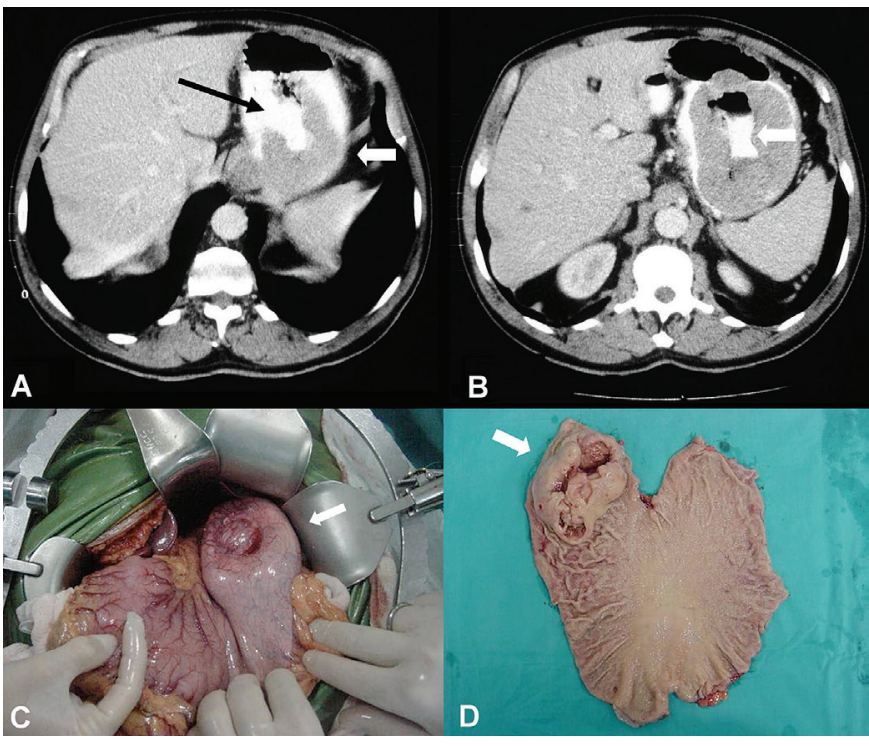

FIGURE 3. A 51 years old female patient, presenting abdominal pain $\mathrm{A}$ and $\mathrm{B}$ : computed tomography with oral and venous contrast showing expansive heterogeneous mass, with central hypodense area and intra/ extraluminal growth, located in the anterior wall of the greater gastric curvature, presenting irregular morphology (arrow); B: hyperattenuation of adjacent mesenteric fat $(*)$, characterizing tumor infiltration.

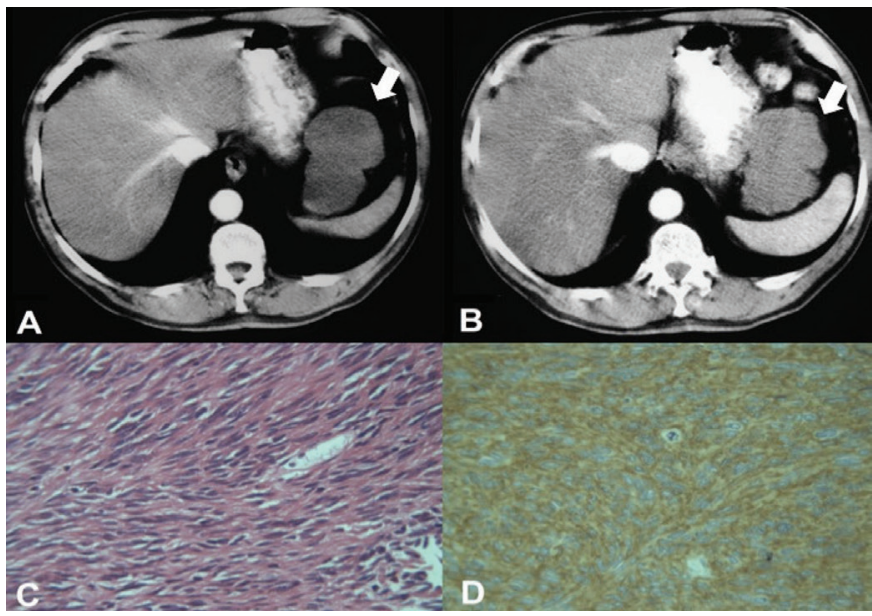

FIGURE 4. A 77 years old female patient, presenting upper digestive hemorrhage

A: computed tomography with oral and venous contrast showing intraluminal vegetative lesion in the upper third of the greater curvature (white arrow), forming a fistulous tract into the gastric lumen (black arrow); B: presence of gas and oral contrast in the lesion (arrow); C: intraoperatory aspect of the lesion (arrow); D: gross pathologic specimen showing intraluminal lesion in the greater curvature (arrow)

TABLE 2 - Correlation between tumor size, growth pattern and enhancement pattern*

\begin{tabular}{lcccccccccc}
\hline & \multicolumn{4}{c}{ Growth pattern } & \multicolumn{4}{c}{ Enhancement pattern } \\
\cline { 2 - 11 }$(\mathbf{c m})$ & \multicolumn{2}{c}{ Extraluminal } & \multicolumn{2}{c}{ Intra/extraluminal } & \multicolumn{2}{c}{ Intraluminal } & \multicolumn{2}{c}{ Heterogeneous } & \multicolumn{2}{c}{ Homogeneous } \\
& $\mathbf{N}$ & $\%$ & $\mathbf{N}$ & $\%$ & $\mathbf{N}$ & $\%$ & $\mathbf{N}$ & $\%$ & $\mathbf{N}$ & $\%$ \\
\hline$<5$ & - & - & - & - & 3 & 100.0 & 1 & 33.3 & 2 \\
$5-10$ & 6 & 60.0 & 3 & 30.0 & 1 & 10.0 & 6 & 66.7 & 3 & 33.3 \\
$>10$ & 4 & 50.0 & 3 & 37.5 & 1 & 12.5 & 7 & 100.0 & - & - \\
\hline
\end{tabular}

*Only for patients receiving intravenous contrast media 
Invasion of adjacent organs was observed in 7 (33.3\%) cases, the most affected being diaphragm, spleen, and pancreas $(\mathrm{n}=3 ; 14.3 \%)$. In only one case $(4.8 \%)$, with high mitotic level, hepatic metastasis were identified.

Statistical analysis showed that irregular morphology $(P=0.027)$ and infiltration of mensenteric fat $(P=0.012)$ correlated with high mitotic index.

\section{DISCUSSION}

Although this is an uncommon tumor, GIST is the most frequent mesenchymal neoplasia of the digestive tract. The disease is more common in the stomach and in individuals who are over 50 years old, with average age varying between 55 and $67^{(29,31)}$. Clinical manifestations are unspecific and depend on the lesion site. Digestive hemorrhage and abdominal pain are the most frequent symptoms found ${ }^{(16,21,23,30,32)}$. Our case comprised $14(66.7 \%)$ female patients and $7(33.3 \%)$ male patients, with average age of 61.6 years old, presenting pain or abdominal discomfort as the most frequent symptom.

Histopathological classification of the tumor is based on the predominant cellular type (fusiform, epithelioid or mixed cells), and the diagnosis through immunohistochemistry assessment, which is based on the expression of the kit protein $(\mathrm{CD} 117)^{(7)}$. GISTs are positive CD117 tumors $(95 \%)$ and positive CD34 $(30 \%-40 \%)^{(7)}$. Some studies have yet demonstrated one alternative route in the disease pathogenesis, characterized by mutation in another receptor tyrosine kinase with activity similar to kit (Platelet-derived growth factor receptor - PDGFRA) ${ }^{(11)}$.

Many factors are identified in the literature as variables capable of predicting the evolution of the GIST, such as size, mitotic index, the presence of tumor necrosis, cellular proliferation markers, and tumor site ${ }^{(8)}$. Whereupon, terms like "benign" or "malign" have been avoided, and GIST has been classified according to the potential malignity based on the most relevant prognostic factors recognized in the literature (tumor site, size, and mitotic index) ${ }^{(26)}$. Gastric tumors can then be classified as high risk, intermediate risk, low risk or very low risk. We consider a tumor as a high risk one if it is bigger than $10 \mathrm{~cm}$, if it presents more than 10 mitosis per HPF, or if bigger than $5 \mathrm{~cm}$ with more than five mitosis per HPF. Intermediate risk tumors are smaller than 5 $\mathrm{cm}$ with 6 to 10 mitosis per HPF or its measure is 5 to $10 \mathrm{~cm}$ with less than five mitosis per HPF. Low risk if its measure is between 2 and $5 \mathrm{~cm}$ with less than five mitosis per HPF; very low risk if its measure is less than $2 \mathrm{~cm}$ with less than five mitosis per $\operatorname{HPF}^{(6,7)}$.

Computed tomography is the most important imaging modality in the characterization of the GIST, as well as in the evaluation of adjacent organs invasion, abdominal metastasis, and response to treatment ${ }^{(1,3,10)}$. Technological improvement of this method has allowed a better assessment of large exophytic tumors and the relations of the gastric lesion with adjacent structures, and allows the characterization of tumors in specific circumstances such as masses of unknown origin or originated from sites inaccessible to endoscopy ${ }^{(4,18)}$.
In the review of literature, the gastric body was the segment most affected by GIST $(38 \%-75 \%)^{(16,21,23)}$, with average size varying between 5.4 and $13.0 \mathrm{~cm}^{(2,20)}$, similarly to what was found in the present study. Tumors smaller than $5 \mathrm{~cm}$ present, still, predominantly intraluminal growth and homogeneous enhancement by venous contrast, while tumors bigger than $10 \mathrm{~cm}$ present extraluminal component and heterogeneous enhancement in most cases ${ }^{(3,13,16,20,27,32)}$. This trend was also observed in our results, where there was a bigger predominance of extraluminal growth among the tumors bigger than $10 \mathrm{~cm}(50 \%)$ and intraluminal growth in all tumors smaller than $5.0 \mathrm{~cm}$. The same way, we found heterogeneous enhancement in $100 \%$ of the tumors bigger than $10 \mathrm{~cm}$ and homogeneous enhancement in $66.7 \%$ of the ones smaller than $5.0 \mathrm{~cm}$.

Other characteristics can still be found especially in tumors of high histological degree, such as mucosa ulceration (3\%-88\%), cavitation and areas of central hypodensity (20\%-49\%) which can correspond to cystic degeneration, hemorrhage or necrosis ${ }^{(9,16,23,29,32)}$. Presence of gas or contrast in the interior of the lesion can suggest presence of mucosa ulceration and fistula formation ${ }^{(18)}$. In our study, we found area of central hypodensity in $52.4 \%$ of the patients, mucosa ulceration in $52.4 \%$ and fistulas in $28.6 \%$. In both three groups, the percentage of patients with high mitotic level was, respectively, $63.7 \%, 63.7 \%$, and $66.7 \%$.

The presence of lymphadenopathy is very rare in patients with GIST and its finding can cogitate the hypothesis of alternative diagnosis ${ }^{(28)}$. Many series do not present any case with this finding ${ }^{(3,22,29,30,32)}$, which is described in up to $2.5 \%$ of cases ${ }^{(16)}$. In our cases, we found one case presenting lymphadenopathy, with mitotic index lower than five mitosis per HPF.

Invasion of adjacent organs can be found in $6.2 \%$ to $20 \%$ of cases ${ }^{(16,22,33)}$ and the presence of metastasis reaches up to $60 \%$ of cases in some series ${ }^{(2,5)}$. Metastatic potential seems to be related to the expression of the immunohistochemistry marker CD $34^{(25)}$, being the liver and the peritoneum the most common sites of occurrence ${ }^{(29)}$. In the present study, we found seven $(33.3 \%)$ patients with invasion of adjacent organs, $57.2 \%$ of them presented high mitotic index and only $1(4.8 \%)$ patient with hepatic metastasis, also presenting mitotic index superior to five mitosis per HPF.

During the latest years, many authors have studied the tomography aspects of the GIST, trying to establish correlations between imaging findings and malignity potential. Kim et al. ${ }^{(16)}$ observed that the presence of ulcer, mesenteric infiltration, invasion of adjacent organs, and presence of metastasis were characteristics more frequent in patients with high mitotic index. However, in the multi-varied analysis, just the size was the predictor for the high mitotic index. Similar results were described by Yang et al. ${ }^{(34)}$. They found correlation between tumors bigger than $5.0 \mathrm{~cm}$ and malignity potential.

Tateishi et al. ${ }^{(32)}$ found statistical correlation between high degree tumors and multiple imaging findings: size bigger than $11.1 \mathrm{~cm}$, extrinsic growth, irregular surface, mesenteric inva- 
sion, hepatic metastasis, and heterogeneous enhancement. Similarly, Ulusan et al. ${ }^{(33)}$ have compared tomography variables and mitotic index. The group with mitotic index higher than five mitosis per $50 \mathrm{HPF}$ presented positive correlation with homogeneous enhancement, tumor size, gastric location, presence of cyst-necrotic component, and presence of metastasis. Other series, however, did not find statistical correlation between imaging characteristics and malignity potential ${ }^{(13,15,21)}$.

In our case, some characteristics were more frequent in the group with high mitotic level, such as size bigger than $10 \mathrm{~cm}$, heterogeneous enhancement, irregular morphology, irregular contour, central hypodensity, mesenteric infiltration, ulceration, fistula, invasion of adjacent organs, and metastasis. However, only irregular morphology and mesenteric infiltration presented statistically significant correlation.

Irregular tumor morphology was observed in five (23.8\%) cases and $80 \%$ of them presented high mitotic index. Only one $(9.1 \%)$ case in the group with mitotic index inferior to 5 presented this characteristic. Jeon et al. ${ }^{(15)}$ found distorted morphology in $20.8 \%$ of the cases, being the frequency of this finding higher in the high-risk group (67\%), if compared to the low-risk group (7\%).

Mesenteric infiltration was also found in $5(23.8 \%)$ patients of the present study, all with high mitotic index, corresponding to $50 \%$ of the patients of this group. Kim et al. ${ }^{(16)}$ found mesenteric infiltration in $9.9 \%$ of the cases, all with high potential of malignity. Similarly, Ulusan et al. ${ }^{(33)}$ found $23 \%$ of the cases with mesenteric infiltration, corresponding to $35.3 \%$ of the patients with high mitotic level. However, no statistically significant correlation was established in these studies.

The reviewed literature presents bigger series with radiology assessment of the GIST. But a few studies correlate imaging findings with malignity potential based on histopathological data, with special interest for gastric tumors. Our series, although small, is concentrated in tumors of the stomach, which may have influenced the results, as many authors have observed different predictions for lesions in other locations ${ }^{(5,7,16,25,26,31,34)}$.

This study presents some limitations. It is a retrospective analysis, with a small number of cases, reviewed in many years in a tertiary institution. Nevertheless, some uncommon findings were observed, such as the statistical correlation between morphology, mesenteric infiltration and high mitotic index, what had not been described so far. These findings if confirmed in bigger series, can help in the identification of the malignity potential of gastric GIST, through imaging characteristics.

\section{CONCLUSIONS}

In the present study, most gastric GISTs were located in the gastric body, with average size of $10.5 \mathrm{~cm}$, presenting round/oval morphology, central hypodense area, ulceration, heterogeneous enhancement and predominantly extraluminal growth. Irregular morphology $(P=0.027)$ and infiltration of mesenteric fat $(P=0.012)$ presented correlated with high mitotic index.

Pelandré GL, Djahjah MC, Gaspareto EL, Nacif MS, Marchiori E, Mello ELR. Aspectos tomográficos do tumor estromal gastrointestinal de origem gástrica e correlação com índice mitótico. Arq Gastroenterol. 2013,50(4):244-50.

RESUMO - Contexto - Tumores estromais gastrointestinais são neoplasias raras e podem acometer qualquer segmento do trato gastrointestinal. A tomografia computadorizada é o método de imagem mais importante na detecção e caracterização do tumor. - Objetivos - Descrever os achados tomográficos do tumor estromal gastrointestinal de origem gástrica, correlacionando com o índice mitótico. Métodos - No período de janeiro de 2000 a dezembro de 2008, foram selecionados 21 pacientes com diagnóstico histopatológico e imunohistoquímico de tumor estromal gastrointestinal, que apresentavam tomografia computadorizada realizada anteriormente ao tratamento. As variáveis tomográficas analisadas foram topografia da lesão, dimensões, contornos, morfologia, padrão e intensidade do realce pelo meio de contraste venoso, padrão de crescimento, invasão de órgãos adjacentes, presença de ulceração, fístula, calcificações, infiltração da gordura mesentérica, linfonodomegalias e metástases. O índice mitótico foi determinado através de microscopia óptica, com contagem do número de figuras de mitoses em 50 campos de grande aumento. Resultados - Os tumores foram localizados no corpo $(66,7 \%$ ) ou fundo gástrico (33,3\%), com dimensões variando entre 4,2 e $21,2 \mathrm{~cm}$ (média de 10,5 cm). O crescimento foi predominantemente extraluminal $(47,6 \%)$ ou intra/extraluminal $(28,6 \%)$. O realce pelo contraste venoso foi heterogêneo em $66.7 \%$. A análise estatística mostrou que morfologia irregular $(P=0.027)$ e infiltração da gordura mesentérica $(P=0,012)$ apresentaram correlação com índice mitótico elevado. Conclusões - No presente estudo, a maioria dos tumores localizava-se no corpo gástrico, com tamanho médio de $10.5 \mathrm{~cm}$, apresentando área hipodensa central, realce heterogêneo pelo meio de contraste e crescimento predominantemente extraluminal. Morfologia irregular e infiltração da gordura mesentérica apresentaram correlação estatística com índice mitótico elevado.

DESCRITORES - Tumores do estroma gastrointestinal. Tomografia computadorizada espiral. Índice mitótico. 


\section{REFERENCES}

1. Blay JY, Bonvalot S, Casali P, Choi H, Debiec-Richter M, Dei Tos AP, Emile JF, Gronchi A, Hogendoorn PC, Joensuu H, Le Cesne A, McClure J, Maurel J, Nupponen N, Ray-Coquard I, Reichardt P, Sciot R, Stroobants S, van Glabbeke M, van Oosterom A, Demetri GD;.GIST consensus meeting panelists. Consensus meeting for the management of gastrointestinal stromal tumors. Report of the GIST Consensus Conference of 20-21 March 2004, under the auspices of ESMO. Ann Oncol. 2005;16:566-78.

2. Burkill GJ, Badran M, Al-Muderis O, Meirion Thomas J, Judson IR, Fisher C, Moskovic EC. Malignant gastrointestinal stromal tumor: distribution, imaging features, and pattern of metastatic spread. Radiology. 2003;226:527-32.

3. Chourmouzi D, Sinakos E, Papalavrentios L, Akriviadis E, Drevelegas A. Gastrointestinal stromal tumors: a pictorial review. J Gastrointestin Liver Dis. 2009; 18:379-83.

4. Da Ronch T, Modesto A, Bazzocchi M. Gastrointestinal stromal tumour: spiral computed tomography features and pathologic correlation. Radiol Med. 2006;111:661-73.

5. DeMatteo RP, Lewis JJ, Leung D, Mudan SS, Woodruff JM, Brennan MF. Two hundred gastrointestinal stromal tumors: recurrence patterns and prognostic factors for survival. Ann Surg. 2000;231:51-8.

6. Efron DT, Lillemoe KD. The current management of gastrointestinal stromal tumors. Adv Surg. 2005;39:193-221.

7. Fletcher CD, Berman JJ, Corless C, Gorstein F, Lasota J, Longley BJ, Miettinen M, O’Leary TJ, Remotti H, Rubin BP, Shmookler B, Sobin LH, Weiss SW. Diagnosis of gastrointestinal stromal tumors: a consensus approach. Hum Pathol. 2002;33:459-65.

8. Fujimoto Y, Nakanishi Y, Yoshimura K, Shimoda T. Clinicopathologic study of primary malignant gastrointestinal stromal tumor of the stomach, with special reference to prognostic factors: analysis of results in 140 surgically resected patients. Gastric Cancer. 2003;6:39-48.

9. Ghanem N, Altehoefer C, Furtwangler A, Winterer J, Schafer O, Springer O, Kotter E, Langer M. Computed tomography in gastrointestinal stromal tumors. Eur Radiol. 2003;13:1669-78.

10. Gong J, Kang W, Zhu J, Xu J. CT and MR imaging of gastrointestinal stromal tumor of stomach: a pictorial review. Quant Imaging Med Surg. 2012;2:274-9.

11. Heinrich MC, Corless CL, Duensing A, McGreevey L, Chen CJ, Joseph N, Singer S, Griffith DJ, Haley A, Town A, Demetri GD, Fletcher CD, Fletcher JA. PDGFRA activating mutations in gastrointestinal stromal tumors. Science. 2003;299:708-10.

12. Hirota S, Isozaki K, Moriyama Y, Hashimoto K, Nishida T, Ishiguro S, Kawano K, Hanada M, Kurata A, Takeda M, Muhammad Tunio G, Matsuzawa Y, Kanakura Y, Shinomura Y, Kitamura Y. Gain-of-function mutations of c-kit in human gastrointestinal stromal tumors. Science. 1998;279:577-80.

13. Horton KM, Juluru K, Montogomery E, Fishman EK. Computed tomography imaging of gastrointestinal stromal tumors with pathology correlation. J Comput Assist Tomogr. 2004;28:811-7.

14. Huizinga JD, Thuneberg L, Kluppel M, Malysz J, Mikkelsen HB, Bernstein A. $\mathrm{W} / \mathrm{kit}$ gene required for interstitial cells of Cajal and for intestinal pacemaker activity. Nature. 1995;373:347-9.

15. Jeon SW, Park YD, Chung YJ, Cho CM, Tak WY, Kweon YO, Kim SK, Choi YH. Gastrointestinal stromal tumors of the stomach: endosonographic differentiation in relation to histological risk. J Gastroenterol Hepatol. 2007;22:2069-75.
16. Kim HC, Lee JM, Kim KW, Park SH, Kim SH, Lee JY, Han JK, Choi BI. Gastrointestinal stromal tumors of the stomach: CT findings and prediction of malignancy. AJR Am J Roentgenol. 2004;183:893-8.

17. Kindblom LG, Remotti HE, Aldenborg F, Meis-Kindblom JM. Gastrointestinal pacemaker cell tumor (GIPACT): gastrointestinal stromal tumors show phenotypic characteristics of the interstitial cells of Cajal. Am J Pathol. 1998;152:1259-69.

18. Lau S, Tam KF, Kam CK, Lui CY, Siu CW, Lam HS, Mak KL. Imaging of gastrointestinal stromal tumour (GIST). Clin Radiol. 2004;59:487-98.

19. Lauwers GY, Erlandson RA, Casper ES, Brennan MF, Woodruff JM. Gastrointestinal autonomic nerve tumors. A clinicopathological, immunohistochemical, and ultrastructural study of 12 cases. Am J Surg Pathol. 1993;17:887-97.

20. Lee CM, Chen HC, Leung TK, Chen YY. Gastrointestinal stromal tumor: Computed tomographic features. World J Gastroenterol. 2004;10:2417-8.

21. Levy AD, Remotti HE, Thompson WM, Sobin LH, Miettinen M. Gastrointestinal stromal tumors: radiologic features with pathologic correlation. Radiographics. 2003;23:283-304.

22. Lupescu IG, Grasu M, Boros M, Gheorghe C, Ionescu M, Popescu I, Herlea V, Georgescu SA. Gastrointestinal stromal tumors: retrospective analysis of the computer-tomographic aspects. J Gastrointestin Liver Dis. 2007;16:147-51.

23. Martín-Lorenzo JG, Aguayo-Albasini JL, Torralba-Martínez JA, Lirón-Ruiz R, Giménez-Bascuñana A, Miquel-Perelló J, Moreno-Egea A, Carrasco-González L. [Gastrointestinal stromal tumors. Diagnosis, prognosis and current surgical treatment. Follow-up of 18 treated patients]. Cir Esp. 2006;79:22-7.

24. Mazur MT, Clark HB. Gastric stromal tumors. Reappraisal of histogenesis. Am J Surg Pathol. 1983; 7:507-19.

25. Miettinen M, Lasota J. Gastrointestinal stromal tumors--definition, clinical, histological, immunohistochemical, and molecular genetic features and differential diagnosis. Virchows Arch. 2001;438:1-12.

26. Miettinen M, El-Rifai W, Sobin L, Lasota J. Evaluation of malignancy and prognosis of gastrointestinal stromal tumors: a review. Hum Pathol. 2002;33:478-83.

27. Nishida T, Kumano S, Sugiura T, Ikushima H, Nishikawa K, Ito T, Matsuda $\mathrm{H}$. Multidetector CT of high-risk patients with occult gastrointestinal stromal tumors. AJR Am J Roentgenol. 2003;180:185-9.

28. Rimondini A, Belgrano M, Favretto G, Spivach A, Sartori A, Zanconati F, Cova MA. Contribution of CT to treatment planning in patients with GIST. Radiol Med. 2007;112:691-702.

29. Sandrasegaran K, Rajesh A, Rushing DA, Rydberg J, Akisik FM, Henley JD. Gastrointestinal stromal tumors: CT and MRI findings. Eur Radiol. 2005;15:1407-14.

30. Sandrasegaran K, Rajesh A, Rydberg J, Rushing DA, Akisik FM, Henley JD. Gastrointestinal stromal tumors: clinical, radiologic, and pathologic features. AJR Am J Roentgenol. 2005;184:803-11.

31. Strickland L, Letson GD, Muro-Cacho CA. Gastrointestinal stromal tumors Cancer Control. 2001;8:252-61.

32. Tateishi U, Hasegawa T, Satake M, Moriyama N. Gastrointestinal stromal tumor. Correlation of computed tomography findings with tumor grade and mortality. J Comput Assist Tomogr. 2003;27(5):792-8.

33. Ulusan S, Koc Z, Kayaselcuk F. Gastrointestinal stromal tumours: CT findings. Br J Radiol. 2008;81:618-23.

34. Yang TH, Hwang JI, Yang MS, Hung SW, Chan SW, Wang J, Tyan YS. Gastrointestinal stromal tumors: computed tomographic features and prediction of malignant risk from computed tomographic imaging. J Chin Med Assoc. 2007;70:367-73. 